Otterbein University

Digital Commons @ Otterbein

Modern Languages \& Cultures Faculty

Scholarship

Modern Languages \& Cultures

2011

\title{
The Paratext to Chrétien de Troyes's Cligés: A Reappraisal of the Question of Authorship and Readership in the Prologue
}

Levilson C. Reis

Otterbein University, Ireis@otterbein.edu

Follow this and additional works at: https://digitalcommons.otterbein.edu/mlanguages_fac

Part of the French and Francophone Literature Commons, Medieval Studies Commons, and the Modern Languages Commons

\section{Repository Citation}

Reis, Levilson C., "The Paratext to Chrétien de Troyes's Cligés: A Reappraisal of the Question of Authorship and Readership in the Prologue" (2011). Modern Languages \& Cultures Faculty Scholarship. 16.

https://digitalcommons.otterbein.edu/mlanguages_fac/16

This Article is brought to you for free and open access by the Modern Languages \& Cultures at Digital Commons @ Otterbein. It has been accepted for inclusion in Modern Languages \& Cultures Faculty Scholarship by an authorized administrator of Digital Commons @ Otterbein. For more information, please contact

digitalcommons07@otterbein.edu. 
THE PARATEXT TO CHRÉTIEN DE TROYES'S CLIGÉS: A REAPPRAISAL OF THE QUESTION OF AUTHORSHIP AND READERSHIP IN THE PROLOGUE

French Studies, 65(1), 1-16

doi:10.1093/fs/knq178

Levilson C. Reis

Otterbein University, Ohio

\section{Abstract}

Starting with the premise that medieval manuscripts exhibit paratextual vestiges of their auctores, redactors, copyists, and readers, this article re-examines the question of authorship and readership in Chrétien de Troyes's prologue to Cligés (c. 1176-80) through the lens of paratextual references to the implied author's signature, allusions to possible titles of his previous works, marginal annotations of interpretative readings, and cases of significant manuscript variance. Firmly grounded in the manuscript, editorial, and critical tradition of Cligés, this reading re-evaluates the tripartite thematic structure of the prologue, hypothesizing the paratextual effect that the opening list of literary titles, the suspenseful presentation of the hero, and the authoritative claim for the location of chevalerie (chivalry) and clergie (culture) in France might have had on medieval audiences and may have on modern readers. Exploring the significantly different versions in which two families of manuscripts transmit the same ideas, this reading finally shows how the prologue equivocates and subverts any one definite interpretation and engenders a sense of irony and alterity that captivates the reader and opens the threshold to new interpretations. 
After all that has been written about the prologues of Chrétien de Troyes's romances, only a provocative claim, like the one I make in the title of this piece, could perhaps justify a return to them, especially to that of Cligés $\left(c .1176-80^{1}\right)$. At the outset, I must admit that invoking the concept of paratext in a manuscript context may indeed appear provocative; but, in defence of such an approach, it can be said that, although manuscripts may not conform to the paratextual paraphernalia one would find in a modern text (such as title, author's name, book cover, and book jacket), their means of transmission, as Gérard Genette submits, 'apporte à l'idéalité du texte une part de matérialisation, graphique ou phonique, qui peut induire [. . .] des effets paratextuels'. ${ }^{2}$ The signature 'Crestiens' that autographs the prologues of Chrétien's works constitutes an example of the textual construction of authorship that originated the rich critical tradition built around the shadowy figure of Chrétien de Troyes. ${ }^{3}$ Early studies of Chrétien's works tried to situate this textually constructed figure in a historical, cultural, and literary milieu to conjure up an author for a corpus that, despite all efforts, still lacks definitive attribution. ${ }^{4}$ The thorny question of authorship rallied specifically around the list of Chrétien's previous works and the relationship between literary craft and the topos of translatio studii in the prologue to Cligés. ${ }^{5}$ In another strand of criticism, the focus shifted from the concern with the author to the quasi-narratological study of the narrator. ${ }^{6}$ This critical orientation turned our attention back to the oral nature of medieval poetics and to the instability of its mode of transmission, which modern editors have attempted to arrest in quest of a definitive text. These critical approaches and editorial choices have brought to light a host of problems, not the least of which remains the application of the modern notion of text (as a closed and finished product) to works 
like Cligés, which constitute no more than 'a composite of variants pointing to a more or less faithful attempt to recover what Chrétien originally wrote'. ${ }^{7}$ Capitalizing on the open manuscript tradition of Cligés, this reading re-examines the question of authorship and readership in the prologue through the lens of paratextual features such as signatures, titles, annotations of interpretative readings, and significant cases of manuscript variance that may influence the reader's reception and interpretation of the text, whether in medieval or modern contexts.

Previous commentary on the first lines of Cligés has belaboured the construction of authorship on the literariness of the prologue and the narrator's attribution of several vernacular adaptations of Celtic and Latin works to the signature 'Crestiens'. Of all these references to the implied author's past literary achievements, only two are actual titles of extant works attributed to Chrétien de Troyes. Érec et Énide, for one, has survived in seven manuscripts dating back to the early thirteenth century, and Philomena, for the other, has been purportedly preserved in the Ovide moralisé (11. 2217-3684). ${ }^{8}$ Although the other references are not recognizable titles, source studies have tentatively identified 'les comandemanz d'Ovide' and 'l'art d'amors' with Ovid's Remedia amoris and Ars amatoria, respectively, 'le mors de l'espaule' with the Pelops episode from Ovid's Metamorphoses (VI. 401-11), and 'Dou roi Marc et d'Iseut la Blonde' with a lost version of the Tristan and Isolde legend. While these extensive intertextual analyses have contributed to our understanding of the vernacular poetic process, they have done little to help us comprehend the effect that those references may have had on medieval audiences.

What modern editors and researchers have come to identify as title references in the first lines of the prologue have really been the result of modern editorial choices. On the 
one hand, these title references may not have been more than allusions. As Paul Zumthor has put it, 'lors même que cet auteur énumère, au début de Cligès, ses ouvrages antérieurs, il les nomme moins qu'il ne les décrit en exposant leur thème'. ${ }^{9}$ On the other, one must also consider that some members of aristocratic circles could not read in their own vernacular dialects (not to mention Latin or Greek), and that the understanding of this intricate intertextuality, which the identification of these classical works presupposes, would require a knowledge of Greek and Latin literatures that (lay) readers did not have. ${ }^{10}$ Medieval audiences generally relied on lectors who read or performed works like Cligés in both private and small, semi-public settings. ${ }^{11}$

The present re-examination of the question of authorship and readership in the prologue to Cligés takes these conditions of reading into account to recontextualize conceptions of authorship and readership within medieval manuscript culture. This reexamination is predicated on the hypotheses that the medieval reading scenarios of Chrétien's Cligés differed according to the approximate date of circulation of the manuscripts and their localization (see Table $1^{12}$ ), and that none of the manuscripts discussed here is a direct copy of each other. Because individual readers or audiences may not have had access to more than one version of the manuscripts, the ideal, yet impractical, approach would be to provide a contextualized scenario for each and every manuscript. Looking at the manuscripts from another perspective (see the last column of Table 1), it becomes evident that significant changes in codicological features of the manuscripts provide a more useful critical framework, which would narrow down our discussion to two possible scenarios. The first scenario would set our discussion in the context of the two earliest large-format codices - Paris, Bibliothèque nationale de 
France (BN), MSS fonds français (f. fr.) 794 and 1450 — which appear to have served as performance copies destined for oral/aural performances in private or semi-public courtly readings. ${ }^{13}$ The second scenario focuses on mid- and late thirteenth-century author-based manuscript collections BN, MSS f. fr. 1420 and 12560, also believed to have served as performance copies for courtly readings or as reference copies in a seigniorial library. Despite its two-pronged approach, the discussion will not fail to evince revealing relationships between these author-based collections and diverse compilations such as BN, MSS f. fr. 1374 and 375, which feature only one or two of Chrétien's romances, including Cligés, but offer alternative points of view that cannot be ignored. ${ }^{14}$ This critical framework will not only situate the question of readership in its medieval context but will also shed light on the early formation of a Chrétien corpus, which can contribute a great deal to a new understanding of how early and late thirteenth-century audiences received Chrétien's work. ${ }^{15}$

TABLE 1 The manuscript tradition of Cligés

\begin{tabular}{|c|c|c|c|c|}
\hline $\begin{array}{l}\text { Manuscript } \\
\text { Paris, BN }\end{array}$ & Siglum & $\begin{array}{l}\text { Date } \\
\text { 13th century }\end{array}$ & Region & $\begin{array}{l}\text { Basic Relevant Codicology } \\
\text { Placement of Cligés and other Chrétien works* }\end{array}$ \\
\hline MS f. fr. 1450 & B & 2nd quarter & North-east & $\begin{array}{l}\text { Historiographical compilation } \\
\text { Romans de Troie, d'Énéas, de Brut, Dolopathos } \\
E, C, P, C, Y \text { inserted into the Roman de Brut }\end{array}$ \\
\hline MS f. fr. 794 & $\mathrm{~A}$ & 2nd quarter & Champagn & $\begin{array}{l}\text { Half-literary, half-historiographical compilation } \\
E, L, C, Y \text { open the collection as a separate set } \\
\text { Athis et Prophilias, Troie, Brut, Empereurs de Rome, P, FC, SC }\end{array}$ \\
\hline MS f. fr. 1374 & $\mathrm{~S}$ & 2nd quarter & South & $\begin{array}{l}\text { Literary compilation } \\
C \text { only among six other vernacular works }\end{array}$ \\
\hline MS f. fr. 1420 & $\mathrm{R}$ & mid-century & Île de & $\begin{array}{l}\text { Author-based collection } \\
E^{\prime} \text { and } C\end{array}$ \\
\hline MS f. fr. 12560 & $\mathrm{C}$ & mid-century & Champagn & $\begin{array}{l}\text { Author-based collection } \\
Y, L, C\end{array}$ \\
\hline MS f. fr. 375 & $\mathrm{P}$ & 3rd quarter & Arras & $\begin{array}{l}\text { Anthology } \\
C \text { and } E^{\prime} \text { within a large variety of works }\end{array}$ \\
\hline
\end{tabular}


First Scenario: Reading from BN, MSS f. fr. 794 and 1450

BN, MS f. fr. 794 will provide the source for the first reading scenario not because it has become the base manuscript for a number of editions, but because of its relative early age (around the first to second quarter of the thirteenth century ${ }^{16}$ ) and vestiges of bookmarks, which attest, as Stewart Gregory and Claude Luttrell have noted, the importance given to the reading of the manuscripts in this early thirteenth-century largeformat codex. ${ }^{17}$ With the story of Cligés in mind, the lector opens the voluminous collection of manuscripts at the third bookmark (fol. 54), as the table of contents on the fourth flyleaf of the volume indicates: 'Cliget qui welt trover la tierce ensoigne proigne' (fol. $\mathrm{C}^{\mathrm{v}}$ ). As the reading begins, the lector assumes the role of a third-person narrator and starts by listing the previous literary productions of an unnamed author before introducing the subject matter of the romance:

Cil qui fist d'Erec et d'Enide,

Et les comandemanz d'Ovide

Et l'art d'amors an romans mist,

Et le mors de l'espaule fist,

Del roi Marc et d'Ysalt la blonde,

Et de la hupe et de l'aronde

Et del rossignol la muance,

Un novel conte rancomance. (M, 11. 1-8) 
He who wrote Erec and Enide, who translated Ovid's Commandments and the Art of Love into French, who wrote The Shoulder Bite, and about King Mark and Isolde the Blonde, and of the metamorphosis of the hoopoe, swallow, and nightingale, begins now a new tale. ${ }^{18}$

For medieval audiences, it would not have been unusual to hear a story without an author's name or without a title. Anonymity of the poet and of the work (that is, the lack of a title) was part and parcel of an oral tradition; it was in fact the author-function of medieval poetics. ${ }^{19}$ The modern reader, on the other hand, may find it strange that neither the title of the book nor the name of the author is given at the beginning of this manuscript, as Micha's edition of MS f. fr. 794 faithfully shows, while later transmission of the same romance in MS f. fr. 12560 (around the mid- to third quarter of the thirteenth century ${ }^{20}$ ) bears a rubricated incipit, as will be discussed in the second scenario below. For the modern reader, the title, the author's name, and the complementary question of self-attribution and authorship, which have been associated with the signature 'Crestiens' in the prologue to Cligés, did not appear in either MS f. fr. 794 or $1450 . .^{21}$

The first reference to 'Crestiens' does not appear in MS f. fr. 794 or 1450 until after the prologue, when 'Crestiens comance son conte' and the story begins (fol. $54^{\mathrm{r}}$ c 43 ; $\mathrm{M}$, 1. 43). In the context of storytelling, the signature 's' intègre au texte, y remplissant une fonction en quelque sorte publicitaire, créant entre l'auditeur et ce qu'on lui fait entendre la fiction d'une connivence personnelle'. ${ }^{22}$ The sense of an implied author's presence or persona resulting from the list of works would not normally have raised the medieval reader's interest in the biographical or literary persona of an implied author. At best, the list of previous works draws attention to the fictionality of the story to come and creates 
a contract with the audience. ${ }^{23}$ Michelle Freeman makes the point that 'the immediate listing of the works - whether in point of fact they were all actually written by Chrétien or not $[\ldots]$ - serves to situate Cligés and to give the reader entry into its meaning, ${ }^{24}$ The context of Érec et Énide and Ovid's treatises on the art of love would have probably brought back memories of Érec's adventures, his marriage to Énide, and the conflict between his knightly and marital duties, foreshadowing an expected tale about a knight's adventure at Arthur's court. The references to Ovid's tale of Procne's revenge against her husband's adultery and the Tristan and Isolde legend would, however, add a curious twist to a forthcoming story set in the context of references to married couples (Érec and Énide, and King Mark and Isolde).

Even for a medieval audience familiar with the vernacular translation of the Procne story and the Tristan and Isolde legend, the relationship between these narratives of adultery and the forthcoming story would require further explanation, as would the description of the romance hero as a Greek relative of King Arthur ('D'un vaslet qui an Grece fu | Del linage le roi Artu', M, 11. 9-10; 'of a youth who, in Greece, was of King Arthur's line', K, p. 123). The suspense rises to the question of how he was related to Arthur and how this reference may have been construed as an indication of what was to come. Some explanation finally comes forth, as the narrator/lector intervenes, addressing the audience directly to introduce the hero's father. One learns that his father was so valiant and brave that he had gone from Greece to England, which was then called Britain, to prove himself through chivalrous deeds and become a knight at Arthur's court: 
Mes ainz que de lui rien vos die,

Orroiz de son pere la vie,

Dom il fu, et de quel linage.

Tant fu preuz et de fier corage

Que por pris et por los conquerre

Ala de Grece an Engleterre,

Qui lors estoit Bretaigne dite. (M, 11. 11-17)

But before I tell you anything of him, you will hear about the life of his father — his origins and lineage. He was so valiant and bold of heart that, in order to win fame and glory, he went from Greece and went to England, which in those days was called Britain. (K, p. 123)

This brief initial account of the story of the hero's father implies that he married a relative of Arthur's lineage, providing, as Tony Hunt has noted, 'essential background knowledge'. ${ }^{25}$ This broad description of the father is, however, only the prelude to the first part of the romance, which deals with the genealogical history of the hero leading up to his birth: 'L'anfant apelerent Cligés. | Ce est Cligés an cui mimoire | Fu mise an romans ceste estoire' (fol. $63^{\mathrm{r}}$ a2344-46; M, 11. 2344-46; '[T]he child they called Cligés [. . .], in whose memory this story was composed in the French tongue', K, pp. 151-52). The reason why the story of Cligés is relegated to second place is not so evident from the point of view of modern readers, as Norris Lacy has remarked. ${ }^{26}$ That may not be the case for medieval readers, as we re-examine the rest of the prologue following the second reading scenario provided by mid-thirteenth-century author-based manuscripts. 
Second Scenario: Reading from Paris, BN, MSS f. fr. 1374, 1420, 12560, and 375

Despite the usual dialectical variances, lines $1-13$ of the prologue are semantically uniform throughout the manuscript tradition of Cligés. Line 14, which describes the father grosso modo, presents the first case of variance in BN, MSS f. fr. 12560 and $375 .{ }^{27}$ In opposition to the rather nondescript characterization of the romance hero's father as 'preuz et de fier corage' (M, 1. 14; 'valiant and bold of heart', K, p. 123) in MS f. fr. 794 (fol. 54 $\mathrm{b} 14$ ), the same descriptive line paints a much more distinctive portrait of the father in MS f. fr. 12560:

Tant fu preuz et de haut parage

Que por pris et por los conquerre

Ala de Grece en Engleterre,

Qui lors estoit Breteigne dite.

(M-C, 11. 14-17, my emphasis)

He was so valiant and of $\left[\right.$ high birth $\left.{ }^{28}\right]$ that, in order to win fame and glory, he went from Greece to England, which in those days was called Britain. (K, p. 123, my emphasis)

For the lectors and audiences of MS fr. 12560 (and 375), the description of the father as a figure of 'de haut parage' (M-C, 1. 14; 'high birth/great pomp' ${ }^{29}$ ) was not meant to upstage the son's place as the romance hero. In fact the genealogical account of family lineage was a necessary component of the telling and showing of medieval romances in the context of which Cligés situates itself. ${ }^{30}$ The scene that recounts the father's arrival at Arthur's court is illustrative: because of the father's physical appearance and dress (M- 
C, 11. 325-29), King Arthur understood at first glance that the approaching newcomer and his companions were high-born men: 'Car bien semblez, et je le cuit, I Que vos estes fil de hauz homes' (M-C, 11. 364-65; 'You appear to be, and I believe that you are, sons of high-born men', K, p. 127). Readers may have similarly marvelled at the description of the father's handsome looks and luxurious clothes when the narrator describes what the hero's father and his entourage were wearing: 'Et les robes que il vestoient | D'un drap et d'une taille estoient, | D'un semblant et d'une color' (M-C, 11. 327-29; 'The clothes they wore were of identical cloth and cut, of one colour and design', K, p. 127). This reading of the text corroborates both acceptations of the lesson 'de haut parage' in MSS f. fr. 12560 and 375.

Lacking such a comparable description of the hero's father, the lector and audience of our first scenario could still have associated the description of a brave noble Greek with the magnificent image of Alexander the Great as soon as the narrator named him 'Alixandres' (M, 1. 57; 'Alexander', K, p. 123) and evoked his largesse (M, 11. 396-405). In our second scenario, especially in readings from MSS f. fr. 1420 and 1374, the association of the Greek father with Alexander the Great or the heroes of the flourishing twelfth-century versions of the Roman d'Alexandre may have been even stronger. ${ }^{31}$ In MS f. fr. 1374 a reader prefixed the title 'Le roman d'Alixandre' in post-medieval script in the upper margin of folio $21^{\mathrm{v}} \cdot{ }^{32}$ Likewise, in the upper margin of MS f. fr. 1420 traces of interpretative readings survive in a post-medieval script: 'Li romant d'Alixandre, fils d'Alixandre empereur de Constantinople, p. 172 et de la belle Sordamours p. 182 et de Clyget leur fils p. 230 et de la belle Phinin p. 238 composé par Cristiens de Troyes p. $171^{\prime} .^{33}$ These post-medieval summaries with page references indicate that readers 
focused on the story of the father and that they associated him with the image of Alexander the Great popularized by twelfth-century versions of the Romans d'Alexandre. ${ }^{34}$ These paratextual annotations indicate, moreover, that the image of the magnificent emperor persisted in the literary imaginary of readers well past the medieval period.

This simple variant had also the potential impact on the construction of authorship of the romance, for the story of the father is inextricably linked to the question of the paternity of the text and to a genealogically established tradition. As we resume the reading of the prologue, the focus passes seamlessly from the genealogy of the hero to that of the manuscript source of his romance, leading us to an important variant lesson provided by the manuscripts in this second reading scenario. As the reading continues, the narrator claims:

Ceste estoire trovons escrite,

Que conter vos vuel et retraire,

En .I. des livres de l'aumaire

Mon seignor saint Pere Beauvez.

De la fu cist contes estrez

Dont cest romanz fist Crestiens.

Li livres est molt anciens

Qui tesmoigne l'estoire a voire:

Por ce fet ele meulz a croirre.

(M-C, 11. 18-26, my emphasis) 
This story that I wish to relate to you we find written down in one of the books in my lord St Peter's Library in Beauvais; the tale from which Chrétien fashions this romance was taken from there. The book containing the true story is very old, therefore it is all the more worthy of belief. (K, p. 123)

In the form of a book found in the library of the church of Saint-Pierre in Beauvais, the manuscript source, which underwrites the father's and the son's stories, not only contains the ancient materia on which the romance is drawn but also the auctoritas that the classical source text bestows on the vernacular romance. This original manuscript would constitute the authoritative foundation for all the manuscripts of Cligés. Ironically, MS f. fr. 1374 offers a different perspective on the origin of the story, casting doubt on the reader's chances to verify the source. In this manuscript, the very book on which Crestiens based his romance was purportedly removed from the library: 'De la fu cist liures retraiz' (fol. $21^{\mathrm{v}}$ a22). ${ }^{35}$ It is also possible, as history informs us, that the original manuscript was burned in a fire that destroyed Saint-Pierre in 1180 and was no longer available. ${ }^{36}$ While the attribution of the father's story to an unnamed Latin written source would guarantee the authoritative account of the father's life and that of the son, the lesson of MS f. fr. 1374, which points to the disappearance of the book, brings the authority of the original manuscript into question, if only to assert the narrative craft of its vernacular composer, as Sharon Kinoshita has perceptively noted:

Both in his acknowledgement of his source and in his attention to the adventures of Alexander, Chrétien's apparent concern with paternity in fact functions, like the topoi of translatio, to establish an ambivalent filiation that 
concedes the importance of the old, all the better to assert the superiority of the new. Consider, for example, the fact that Saint Peter's of Beauvais, the library putatively housing Chrétien's source, burned in 1180. If we conjecture that Cligés was composed after this event, then the destruction of the Latin text, surviving now only as a vanished subtext, authorizes Chrétien's work while in fact liberating him from the tyranny of traditional authority altogether. ${ }^{37}$

This lesson from MS f. fr. 1374, the likelihood that the original manuscript burned in the library fire, and Kinoshita's implications of such a loss not only offer another terminus a quo for Cligés (as Favati had already argued ${ }^{38}$ ), but, most importantly, they relocate the originality of the romance in Chrétien's craftsmanship. Right after its reported disappearance, Chrétien emerges as the redactor of the romance: 'De la fu cist liures retraiz | Dont cest romanz fist Crestians. | Li liures est ml't anciens' (MS f. fr. 1374, fol. $21^{v}$ a22-24; The book from which Chrétien fashions this romance was removed from there [the Beauvais Church library]. The book containing the true story is very old, my translation). Line 23 is part of a couplet that first appeared in column a, lines $23-24$ of the prologue to Cligés in MSS f. fr. 1420 (fol. 30), 12560 (fol. 83v), 1374 (fol. 21), and 375 (fol. $267^{v}$ ). That couplet was not originally in MS f. fr. 794 or 1450 . The appearance of this self-attribution of the redaction of Cligés contributes greatly to the early (medieval) formation of a Chrétien corpus. ${ }^{39}$ Not only does the signature 'Crestiens' in Cligés establish for the first time a connection with the signature 'Crestiens de Troies' in the prologue to Érec et Énide, ${ }^{40}$ but it also associates the term 'roman' not with a 'vernacular 
translation' as it appears in the opening lines of the prologue to Cligés (' $[\ldots]$ en romanz mist', M-C, 1. 3) but, as Kelly has noted, with a literary genre - the romance. ${ }^{41}$

MS f. fr. 12560 in particular contributed even further to the formation of a Chrétien corpus by distinguishing itself as the first one of Chrétien's manuscripts to bear rubricated incipits identifying their contents as 'romances' ${ }^{42}$ The addition of titles coincides with a change in the scribal practice of writing below the top ruled line, to which N. R. Ker first brought attention in an attempt to establish that in thirteenthcentury manuscripts 'up to a certain period every page of writing is, as it were, open at the top: there is nothing but the margin above the first line of writing', but some time after the mid-thirteenth century, up-to-date scribes started to write 'below top line' ${ }^{43}$ The top ruled line would thus literally create a space for the inscription of incipits in Chrétien's works in MS f. fr. 12560 for the first time. According to Terry Nixon, this is the 'earliest Chrétien manuscript written below the top line' ${ }^{44}$ In light of the emergence of these elements of mise en page, I would argue that the authorial figure that emerges in Chrétien's works evolved as a result of changes in manuscript culture, despite the claim of translatio studii et imperii.

The authorial image of authorship that Chrétien claims for himself is affiliated with a glorious classical (written) tradition and ensured by the principle of translatio studii et imperii, as the narrator authoritatively states in the following lines:

Par les livres que nous avons

Les faiz des anciens savons

Et dou siecle qui fu jadis.

Ce nos ont nostre livre apris 
Que Grece ot de chevalerie

Le premier los et de clergie,

Puis vint chevalerie a Rome

Et de la clergie la somme,

Qui or est en France venue.

(M-C, 11. 27-35)

Through the books we have, we learn of the deeds of ancient peoples and of bygone days. Our books have taught us that the chivalry and learning first [belonged to ${ }^{45}$ ] Greece; then to Rome came chivalry and the sum of knowledge, which now has come to France. (K, p. 123)

Previously considered historically disconnected, the topoi of studium (bookish learning) and imperium (imperial power) resurge in this last section of the prologue as an integrated historical migration from East to West in the form of chevalerie (chivalrous knighthood) and clergie (clerical culture), medieval concepts derived from the twinned topos of the translatio studii et imperii. ${ }^{46}$ Tellingly, chevalerie takes the front seat in the translatio, yet the manuscript seems to equivocate as to whether it ultimately came to France. The last two lines of this section seem to indicate that only clergie finally came to reside in France, especially if one considers 'nostre livre' (M-C, 1. 30; 'our books', K, p. 123) as evidence to the fact. ${ }^{47}$ Although clergie (as the skilful conjoining of the classical and the vernacular) has often been privileged in literary interpretations of this passage, it could be argued that the account of our heroes' chivalric pilgrimages from Constantinople to Arthur's court gives equal importance to the topos of chevalerie. Whether chevalerie or clergie found a home in France is not as significant as the 
alternative reading that MSS f. fr. 794 and 1450 offer on the question of the origin and location of the twinned topoi.

While lines a31-32 of MS f. fr. 12560 (fol. $83^{v}$, as well as those same lines in the other manuscripts of its group ${ }^{48}$ ) identify Greece as the origin of chevalerie and clergie, lines b29-30 of MS f. fr. 794 (fol. 54) and lines b28-29 of 1450 (fol. 188v) subtly sublate the claim that Greece was their original location with the counterpoint that the Greeks were (only) the first to recognize their value ('Qu'an Grece ot de chevalerie | Le premier los et de clergie' (M, 11. 29-30; 'Chivalry and learning first flourished in Greece', K, p. 123, my emphases).$^{49}$ Although the variance between these two versions is minimal, its semantic significance is considerable. The locative prepositional phrase 'an Grece' makes remarkable contrast side by side with the subject position of 'Grece'. As an adverbial phrase of the subordinate relative clause in MS f. fr. 794, Greece situates itself as the first location of chevalerie and clergie and not as their point of origin.

Similarly, right after the migratory concept of translatio is introduced, the lesson maintenue, present in MS f. fr. 794 (and in 1420), further casts in doubt the passage of chevalerie and clergie from Greece, to Rome, and to France specially in relation to MSS $\mathrm{f}$. fr. 12560, 1374, and 375, represented here by Méla and Collet's edition of MS f. fr. 12560:

BN, MS f. fr. 12560

Dex doint qu'ele i soit retenue

Tant que li leus li embelisse

Si que ja mais de France n'isse

L'ennors qui s'i est arestee.
BN, MS f. fr. 794

Dex doint qu'ele i soit maintenue

$[\ldots]$

(M, 1. 34, my emphasis) 
Dex l'avoit as altres prestee,

Que des Grezois ne des Romains

Ne dit en mais ne plus ne mains,

D'eus est la parole remese

Et esteinte la vive brese.

(M-C, 11. 36-44, my emphasis)

The variant maintenue may suggest that, even before their putative migration from Athens to Rome to Paris, chevalerie and clergie (or the latter alone, as the pronoun 'ele' on 1. 34 may imply) had already been firmly established in France. In their edition of Cligés, based on MS f. fr. 794, Gregory and Luttrell explain their adoption of the lesson retenue from the other manuscripts because '[1]a leçon maintenue (mss. AR) trahit l'image dévéloppée par le poète, où de la clergie la some est traité d'entité migratrice venue en France, et le désir exprimé par ce vers, c'est que cette hôte étrangère soit persuadée d'y rester'. ${ }^{50}$ This statement reads en filigrane that clergie would be more likely associated with retenir, although it would be difficult to corroborate such a statement, since clergie 'is rarely evoked in Chrétien's romances' ${ }^{51}$ Godefroy's Dictionnaire de l'ancienne langue française does attest the use of maintenir (as 'conserver', 'garder', and 's'occuper de') in the context of a certain type of endeavour ('mestier' and 'œuvre'). ${ }^{52}$ We know enough about the self-proclaimed scribe Guiot of MS f. fr. 794 to posit that he believed that clergie (qua clerkly culture) was well established in France (in Provins, Champagne), as his colophon at the end of his copy of Yvain advertises: 'Cil qui l'escrist guioz a non I Devant nostre dame de val | Est ses ostex tot a estal' (fol. $105^{\mathrm{r}} \mathrm{c}$; 'He who wrote it is named Guiot, and his market stall is located in front of Notre-Dame-du-Val', my 
translation). Moreover, the use of the variant maintenue in lieu of the predominant lesson retenue expresses the wish in line 36 that it be maintained, supported, or patronized, all acceptations of the verb maintenir. ${ }^{53}$

The verb retenir, on the other hand, is used specifically in the context of chevalerie in MS f. fr. 794. When Alexandre arrives at Arthur's court and offers his services to the king, he refers to himself as chevalerie incarnate: 'Se vos tant mon servise amez | Que chevalier me vuilliez faire, | Retenez moi, rois debonaire' (M, 11. 350-52; 'If you esteem my service highly enough to make me a knight, then retain me, gentle king', K, p. 127, my emphases). It appears that Alexander did not bring chevalerie along with him, for it was already well established in the West, as evidenced by his reference to the 'renomee' of Arthur's court and his fervent desire to be knighted by King Arthur himself: 'Rois, li renons qui de vos cort | M'a amené a vostre cort | Por vos servir et enorer' (M, 11. 34143; 'My lord king, your widespread fame has brought me to your court to serve and honour you', K, p. 127). ${ }^{54}$ Before he died, Alexander had exhorted his son Cligés to measure himself against the Britons and the English (M, 11. 2565-70) ${ }^{55}$ He takes his father's advice and during the Oxford Tournament defeats all the great knights of the Round Table. After accomplishing many chivalric exploits in Britain, France, and Normandy, Cligés, the new titleholder of chevalerie, decides to return to Greece, and even Arthur cannot retain him: '[...] molt pesa, si con je croi, | Mon seignor Gauvain et le roi, I Quant plus nel pueent retenir' (M, 11. 5027-29, my emphasis; 'It was very sad for my lord Gawain and the king, I believe, not to be able to detain him any longer', $\mathrm{K}, \mathrm{p}$. 185). This evidence further indicates that, from the point of view of MS f. fr. 794 in particular, it was imperative to 'maintain' clergie, for chevalerie was difficult to retain. 
The last verses of the prologue further conspire to dismiss chevalerie and clergie as a heritage come down from the Greeks and the Romans. The manuscript enlists God as the ultimate source of clergie and states that He had only lent it to the Greeks and Romans. The prayer that precedes the final verses of the prologue, which verge on the question of secular decadence (the topos of finis saeculi ${ }^{56}$ ), wishes that chevalerie and clergie never leave France. In the case of chevalerie, a 'French' Cligés ‘[v]estuz a guise de François' (M, 1. 4934; M-C, 1. 4926; 'dressed [...] in the French style', K, p. 184) seems to be the answer to that prayer, as the knights of the Round Table recognize, echoing the last lines of the prologue evoking the burning ambers of Greek and Roman cultures: '[a]ussi s'estaignent et abaissent | Nos proeces devant les voz' (M-C, 11. 4948-49; 'so our fame fades and dwindles before yours', K, p. 184).

\section{Conclusions}

This paratextual reading of the prologue of Cligés leads us to draw several conclusions. First, it corroborates previous interpretations of the prologue as an ironic point of entry that destabilizes and decentres any one particular program of reading: anonymity and/or authorial self-consciousness, antiquity and/or modernity, paternity and/or filiation, Greco-Byzantine and/or Arthurian culture, translatio studii and/or translatio imperii, chevalerie and/or clergie. The variance between manuscripts, as we have seen, accentuates these semantic, structural, and axiological double takes considerably. Second, this sense of instability informs not only the medieval storyteller's reliance on narrative strategies that produce an ironic connivance between an implied author or narrator and his audience but also the uncanny alterity that medieval manuscript culture awakens in the 
modern reader. The great deal of interest and suspense that the prologue undoubtedly aroused in the medieval reader stems from the suspenseful strategies of vernacular poetics itself. As a rule, the lack of titles, the playful postponement of the author's name, the suspenseful deferment of the romance hero's identity, the narratorial interventions, and the relentless ironic complicity between the (not-yet) text, its author/redactor, narrator/lector, and its listener/reader were staple attributes of medieval oral performances.

For the modern reader, the ironic axiological structure that reigns throughout the prologue, and the sense of alterity that emerges, can be explained by the open and rich nature of the manuscript tradition of Cligés, which exhibits a great deal of mouvance. ${ }^{57}$ The variance through which the two families of manuscripts discussed here transmit the same ideas and their ultimate significance may have been motivated by the historical and local contexts of the manuscripts themselves. The codicological structures and features that would consolidate the Chrétien corpus are most evident in the canonical stance that MS f. fr. 12560 adopted in contrast to the less canonical, perhaps downright subversive, version of the earlier MSS f. fr. 794 and 1450. The latter reflects perhaps the earlier state of a manuscript culture, which evolved and led to the 'entitlement' (in both senses of the term) of a new genre with a certain degree of identity, as the incipit of Cligés in MS f. fr. 12560 testifies. These paratextual and textual inconsistencies of the medieval manuscript tradition of Cligés, which modern editors have tried to control or eliminate under good intentions, need to be maintained and reflected in readings of such works so that modern readers may really be able to understand medieval works like Cligés. The 
sense of instability and strangeness that they may cause is minimized by the richness and joy that such readings offer to the reader at the threshold of a marvellous fictional world. 


\section{Endnotes}

I should like to express my gratitude to Professor Lori Walters at Florida State University for introducing me to Chrétien de Troyes and the study of his works in their manuscript context.

${ }^{1}$ Because of veiled textual allusions to contemporary historical events, the period 1170-76 has been widely accepted as the terminus a quo for Cligés, as initially proposed by Stefan Hofer in 'Streitfragen zu Kristian: eine neue Datierung des Cligés und der übrigen Werke Kristians’, Zeitschrift für französische Sprache und Literatur, 60 (1936-37), 441-55 (pp. 441-43), and later by Anthime Fourrier in 'Encore la chronologie des œuvres de Chrétien de Troyes’, Bulletin bibliographique de la Société Internationale Arthurienne/Bibliographical Bulletin of the International Arthurian Society, 2 (1950), 69-88 (p. 51). More recently, scholars have suggested a date after 1180: see Guido Favati, 'Le Cligès de Chrétien de Troyes dans les éditions critiques et dans les manuscrits', Cahiers de civilisation médiévale ( $X^{e}-X I I^{e}$ siècles), 10 (1967), 385-407 (p. 406); and Sharon Kinoshita, ‘The Poetics of Translatio: French-Byzantine Relations in Chrétien de Troyes’s Cligés’, Exemplaria, 8.2 (1996), 315-54 (p. 335 n. 48). For further discussion of this alternative date see below in this article.

${ }^{2}$ Gérard Genette, Seuils (Paris: Seuil, 1987), p. 9. This paratextual reading of the prologue follows in the footsteps of three recent studies that privilege the relationship between text and paratext (running titles, marginal annotations, etc.) in medieval manuscript traditions:

William W. E. Slights, 'Back to the Future — Littorally: Annotating the Historical Page', in The Future of the Page, ed. by Peter Stoicheff and Andrew Taylor (Toronto: University of Toronto Press, 2004), pp. 71-89; Bernhard Pabst, 'Text und Paratext als Sinneinheit? Lehrhafte Dichtungen des Mittelalters und ihre Glossierung', in Wolfram-Studien XIX: Text 
und Text in lateinischer und volkssprachiger Überlieferung des Mittelalters (Freiburger Kolloquium 2004), ed. by Eckart Conrad Lutz, Wolfgang Haubrichs, and Klaus Ridder (Berlin: Schmidt, 2006), pp. 117-45; and Michael Stolz and Gabriel Viehhauser, 'Text und Paratext: Überschriften in der "Parzival”-Überlieferung als Spuren mittelalterlicher Textkultur', in Wolfram-Studien XIX, ed. by Lutz, Haubrichs, and Ridder, pp. 317-35.

${ }^{3}$ I borrow this characterization of Chrétien from Sarah Kay, 'Who Was Chrétien de Troyes?', Arthurian Literature, 15 (1997), 1-35 (p. 25).

${ }^{4}$ See, for example, Stefan Hofer, Chrétien de Troyes: Leben und Werk des altfranzösischen Epikers (Graz-Cologne: Hermann Böhlaus, 1954), and Jean Frappier, Chrétien de Troyes: l'homme et l'œuvre (Paris: Hatier-Boivin, 1957). For the earliest attention given to Chrétien's literary background, especially in the context of the prologues, see Tony Hunt, 'The Rhetorical Background to the Arthurian Prologue', Forum for Modern Language Studies, 6 (1970), 1-23; Tony Hunt, 'Tradition and Originality in the Prologues of Chrestien de Troyes', Forum for Modern Language Studies, 8 (1972), 320-44; Pierre-Yves Badel, 'Rhétorique et polémique dans les prologues de romans au Moyen Âge’, Littérature, 20 (1975), 81-94; Michelle Freeman, 'Chrétien’s Cligés: A Close Reading of the Prologue’, Romanic Review, 67 (1976), 89-101; Tony Hunt, ‘Chrétien’s Prologues Reconsidered', in Conjunctures: Medieval Studies in Honor of Douglas Kelly, ed. by Keith Busby and Norris J. Lacy (Amsterdam: Rodopi, 1994), pp. 153-68; and Adolf G. Beckmann, 'Les Premiers Vers du Cligés', Romania, 122 (2004), 202-05 (p. 203).

${ }^{5}$ See, for example, Freeman, 'Chrétien’s Cligés'; Michelle Freeman, The Poetics of 'Translatio studii' and 'Conjointure': Chrétien de Troyes’s 'Cligés' (Lexington, KY: French Forum, 1979); Michelle Freeman, 'Cligés', in The Romances of Chrétien de Troyes: A 
Symposium, ed. by Douglas Kelly (Lexington, KY: French Forum, 1985), pp. 89-131; and Karl D. Uitti, ‘Chrétien de Troyes’s Cligés: Romance Translatio and History’, in Conjunctures, ed. by Busby and Lacy, pp. 545-57. For a recent re-evaluation of the topoi of translatio studii et imperii see Kinoshita, 'The Poetics of Translatio'; and Sharon Kinoshita, ‘Chrétien de Troyes’s Cligés in the Medieval Mediterranean’, Arthuriana, 18.3 (2008), 4861.

${ }^{6}$ Marie-Louise Ollier, 'The Author in the Text: A Study of the Prologues of Chrétien de Troyes’, Yale French Studies, 51 (1974), 26-41; Norris J. Lacy, ‘The Narrator and his Story’, in The Craft of Chrétien de Troyes: An Essay on Narrative Art (Leiden: Brill, 1980), pp. 3466; Douglas Kelly, 'Chrétien de Troyes: The Narrator and his Art', in Romances of Chrétien de Troyes, ed. by Kelly, pp. 13-47; Yves Ferroul, 'Propédeutique à une lecture du prologue du Cligès', Bien dire et bien aprandre, 5 (1987), 57-71; Evelyn Mullally, 'Cligés', in The Artist at Work: Narrative Technique in Chrétien de Troyes (Philadelphia: American Philosophical Society, 1988), pp. 59-110; Anna Kukułka-Wojtasik, ‘Chrétien de Troyes — créateur et poète: les manifestations du je et leur valeur', in L' 'Effet auteur' au Moyen Âge: actes du colloque d'Amiens (mars 2001), ed. by Danielle Buschinger (Amiens: Presses du Centre d'études médiévales, Université de Picardie-Jules Verne, 2003), pp. 78-85.

${ }^{7}$ Douglas Kelly, 'Preface', in Romances of Chrétien de Troyes, ed. by Kelly, pp. 11-12. Owing to the large number of variants in the manuscripts of Cligés, Margot van Mulken has concluded that 'the Cligés is not a closed, but an open manuscript tradition'; van Mulken, 'The Manuscript Tradition of the Cligés of Chrétien de Troyes: A Stemmatological Approach', in Studies in Stemmatology II, ed. by Pieter van Reenen, August den Hollander, and Margot van Mulken (Amsterdam: Benjamins, 2004), pp. 113-24 (p. 115). 
${ }^{8}$ Ovide moralisé, ed. by Cornelis de Boer, 5 vols (Amsterdam: Johannes Müller, 1915-38), II, 337-66.

${ }^{9}$ Paul Zumthor, Essai de poétique médiévale (Paris: Seuil, 1972), p. 74.

${ }^{10}$ See Brian Stock, 'Two Traditions', in The Implications of Literacy: Written Language and Models of Interpretation in the Eleventh and Twelfth Centuries (Princeton, NJ: Princeton University Press, 1983), pp. 13-18; Michael T. Clanchy, 'Literate and Illiterate’, in From Memory to Written Record: England 1066-1307, 2nd edn (Oxford: Blackwell, 1993), pp. 224-52; and Paul Zumthor, 'Litteratus/Illitteratus: Remarques sur le contexte vocal de l’écriture médiévale', Romania, 106 (1985), 1-18 (p. 3-5).

11 Joseph J. Duggan, 'Oral Performance of Romance in Medieval France’, in Continuations: Essays on Medieval French Literature and Language in Honor of John L. Grigsby, ed. by Norris J. Lacy and Gloria Torrini-Roblin (Birmingham, AL: Summa Publications, 1989), pp. 51-61; Evelyn B. Vitz, Orality and Performance in Early French Romance (Woodbridge: Brewer, 1999); Douglas Kelly, 'Narrative Poetics: Rhetoric, Orality and Performance’, in A Companion to Chrétien de Troyes, ed. by Norris J. Lacy and Joan T. Grimbert (Woodbridge: Brewer, 2008), pp. 52-63 (p. 52); Levilson C. Reis, 'From Aural Reception to Visual Paratext: The Reader in the Manuscripts of Chrétien de Troyes’s Romances’, Neophilologus, 94 (2010), 377-89.

12 Based on Alexandre Micha, 'Liste et description des manuscrits', in La Tradition manuscrite des romans de Chrétien de Troyes (Paris: Droz, 1939; repr. Geneva: Droz, 1966), pp. 28-64; Stewart Gregory and Claude Luttrell, 'The Manuscripts of Cligés', in Les Manuscrits de Chrétien de Troyes/The Manuscripts of Chrétien de Troyes, ed. by Keith 
Busby and others, 2 vols (Amsterdam: Rodopi, 1993), I, 67-95; and Terry Nixon, 'Catalogue of Manuscripts', in Manuscrits de Chrétien de Troyes, ed. by Busby and others, II, 1-85.

${ }^{13}$ For magisterial codicological presentations of these manuscripts see, for BN, MS f. fr. 794, Mario Roques, 'Le Manuscrit fr. 794 de la Bibliothèque nationale et le scribe Guiot', Romania, 73 (1952), 177-99; and, for MS f. fr. 1450, especially in its relationship to MS f. fr. 794, Lori Walters, 'Le Rôle du scribe dans l'organisation des manuscrits des romans de Chrétien de Troyes’, Romania, 106 (1985), 303-25 (pp. 303-17). On the question of performance see, for example, Roques, 'Le Manuscrit fr. 794', p. 191; and Keith Busby, Codex and Context: Reading Old French Verse Narrative in Manuscript, 2 vols (Amsterdam: Rodopi, 2002), I, 136-37.

${ }^{14}$ For a narrative description of this second group of manuscripts see Gregory and Luttrell, 'The Manuscripts of Cligés'; and Christine Ruby, 'Mise en page et mise en texte dans les manuscrits des romans de Chrétien de Troyes (XIII ${ }^{\mathrm{e}}-\mathrm{XIV}^{\mathrm{e}}$ siècles)', 2 vols (unpublished doctoral thesis, Université Paris Sorbonne-Paris IV, 2000), I, 79-234. In reference to BN, MS f. fr. 12560 in particular, see Roger Middleton, 'The Manuscripts', in The Arthur of the French: The Arthurian Legend in Medieval French and Occitan Literature, ed. by Glyn S. Burgess and Karen Pratt (Cardiff: University of Wales Press, 2006), pp. 8-92 (p. 32).

${ }^{15}$ In the subsequent discussion, unless reference to a specific manuscript version of Cligés is called for, quotations will be taken from the following editions: for the manuscripts informing the first reading scenario (based on BN, MS f. fr. 794), Les Romans de Chrétien de Troyes édités d'après la copie de Guiot (Bibl. nat. fr. 794), ed. by Alexandre Micha, II: Cligés (Paris: Champion, 1957), designated 'M'; and, for the second scenario (based on BN, MS f. fr. 12560), Cligés, ed. by Charles Méla and Olivier Collet, in Chrétien de Troyes, 
Romans, suivis des 'Chansons', avec, en appendice, 'Philomena', ed. by Michel Zink and others, Pochothèque/Livre de poche (Paris: Librairie Générale Française, 1994), designated 'M-C'. Page references, together with the appropriate abbreviation, will be given in the text. Critical references will also be made to Chrétien de Troyes: Cligés, ed. by Stewart Gregory and Claude Luttrell (Woodbridge: Brewer, 1993); Cligés, ed. by Philippe Walter, in Chrétien de Troyes, Euvres complètes, ed. by Daniel Poirion and others, Pléiade (Paris: Gallimard, 1994); Chrétien de Troyes, Cligés, ed. by Laurence Harf-Lancner (Paris: Champion, 2006); and Chrétien de Troyes, Cligès, Philomena, Chansons, ed. by Michel Rousse (Paris: Flammarion, 2006).

${ }^{16}$ Wendelin Foerster dated this manuscript to the beginning of the thirteenth century (Christian von Troyes sämtliche Werke nach allen bekannten Handschriften, ed. by W. Foerster and Alfons Hilka, 5 vols (Halle: Niemeyer, 1884-1932), I: Cligés (1884), i-lxxvi (p. xxvii)), while Micha dated it to the mid-thirteenth century (Tradition manuscrite, p. 33). 17 'Introduction', in Cligés, ed. by Gregory and Luttrell, pp. vii-xxxviii (p. ix); and Gregory and Luttrell, 'Manuscripts of Cligés', p. 74.

${ }^{18}$ Cligés, trans. by William W. Kibler, in Chrétien de Troyes, Arthurian Romances, trans. by W. W. Kibler and Carleton W. Carroll (London: Penguin, 1991), pp. 123-205 (p. 123). Unless otherwise stated, quotations are taken from this edition, designated ' $\mathrm{K}$ ', and page references will be given in the text.

${ }^{19}$ On both points see Zumthor, Essai, p. 67-68; on the anonymity of the author see Daniel Poirion, 'Introduction', in Euvres complètes, ed. by Poirion, pp. ix-xliii (p. x). In terms of anonymity as the equivalent of our modern concept of author-function see Kay, 'Who Was Chrétien de Troyes?', pp. 32-33 n. 100. 
${ }^{20}$ While Micha (Tradition manuscrite, p. 38) and Philippe Walter ('Note sur le texte et sur la traduction', in Euvres complètes, ed. Poirion, pp. 1131-36 (p. 1132)) loosely date this manuscript to the thirteenth century, Méla and Collet date it to the third quarter of the thirteenth century ('Établissement du texte’, in M-C, pp. 287-89 (p. 287)), as do Gregory and Luttrell ('Introduction', in Cligés, p. xiii).

${ }^{21}$ Michelle Freeman ('Chrétien’s Cligés', p. 91; Poetics of 'Translatio studii' and 'Conjointure', p. 26) noted that it was unusual that the signature 'Crestiens' did not appear in MS f. fr. 794 and (erroneously) in MS f. fr. 1420 (rather, in MS f. fr. 1450, as she correctly notes later in Poetics, p. 178 n. 7). In his 1884 edition of Cligés, Foerster had already indicated that the lines that contained the reference to 'Crestiens' in the prologue were missing in MSS f. fr. 794 and 1450 (Sämtliche Werke, I, 1). So did Gregory and Luttrell in their 1993 edition of Cligés (p. 1).

${ }^{22}$ Zumthor, Essai, p. 65.

${ }^{23}$ On this notion of the reading contract see Lacy, 'The Narrator and his Story', pp. 37-38; and Peter Haidu, Aesthetic Distance in Chrétien de Troyes: Irony and Comedy in 'Cligès' and 'Perceval' (Geneva: Droz, 1968), p. 26.

${ }^{24}$ Freeman, 'Chrétien’s Cligés’, p. 97. For more recent discussion of the concept of horizon of expectation in Cligés see Keith Busby, 'The Characters and the Setting', in The Legacy of Chrétien de Troyes, ed. by Norris J. Lacy, Douglas Kelly, and K. Busby, 2 vols (Amsterdam: Rodopi, 1987), I, 57-89 (pp. 67-68). Beate Schmolke-Hasselmann was the first to apply Hans Robert Jauss's concept of Erwartungshorizont (horizon of expectation) to the Arthurian romance (The Evolution of Arthurian Romance: The Verse Tradition from Chrétien to Froissart, trans. by M. and R. Middleton (Cambridge: Cambridge University Press, 1998), 
pp. 41-55). See also Schmolke-Hasselmann's concept of the Arthurian beginning ('der arthurische Romananfang') in her 'Untersuchungen sur Typik des arthurischen Romananfangs', Germanisch-Romanische Monatsschrift, n.s., 31 (1981), 1-13.

${ }^{25}$ Hunt, ‘Tradition and Originality’, p. 332.

${ }^{26}$ Lacy, Craft of Chrétien de Troyes, p. 81.

${ }^{27}$ Focusing on the later reception of Cligés via author-based collections, this second scenario focuses primarily on BN, MS f. fr. 12560.

${ }^{28}$ None of the English translations of Cligés has taken this variant into account. 'De haut parage' could also be translated as 'noble birth’ according to the Old French-English Dictionary, ed. by Alan Hindley, Frederick W. Langley, and Brian J. Levy (Cambridge: Cambridge University Press, 2006), p. 467.

${ }^{29}$ While Méla and Collet translated 'de haut parage’ into modern French as 'de si haute naissance' (M-C, p. 291), the former could also mean 'of great pomp'. The two acceptations of the word 'parage' are attested in the Dictionnaire de l'ancienne langue française, ed. by Frédéric Godefroy, 10 vols (Nendeln: Kraus Reprint, 1969), v, 736-38. Freeman points out that 'parage may mean both parenté and ornement, two themes of importance in Cligés, of greater importance, perhaps, than fier corage' (Poetics of 'Translatio studii' and 'Conjointure', p. 178 n. 6); yet, the relative importance of the double meaning of 'parage' remains unexplained in Freeman's note. One possible interpretation comes from the practice of twelfth-century aristocracy to sign its social status through sartorial signifiers; see Howard Bloch, Etymologies and Genealogies: A Literary Anthropology of the French Middle Ages (Chicago: University of Chicago Press, 1983), p. 75.

${ }^{30}$ Bloch, Etymologies and Genealogies, pp. 75-82. 
${ }^{31}$ See Laurence Harf-Lancner, 'Introduction’, in Cligès, ed. by Harf-Lancner, pp. 9-52 (pp. 15-16).

${ }^{32}$ For a published reproduction of fol. $21^{\mathrm{v}}$ of BN, MS f. fr. 1374 see Figure 76 in Manuscrits de Chrétien de Troyes, ed. by Busby and others, II, 411. See also Micha’s comments on this title in his description of this manuscript (Tradition manuscrite, p. 42).

${ }^{33}$ For a published reproduction of fol. $30^{\mathrm{r}}$ of BN, MS f. fr. 1420 see Figure 82 in Manuscrits de Chrétien de Troyes, ed. by Busby and others, II, 417. See also Micha’s description of these subject headings (Tradition manuscrite, pp. 34-35).

${ }^{34}$ See Catherine Gaullier-Bougassas, ‘Alexandre le Grand et la conquête de l’Ouest dans les Romans d'Alexandre du $\mathrm{XII}^{\mathrm{e}}$ siècle, leurs mises en prose au $\mathrm{XV}^{\mathrm{e}}$ siècle et le Perceforest', Romania, 118 (2000), 83-104, and her 'L’altérité de l’Alexandre du Roman d'Alexandre, et en contrepoint, l’intégration à l'univers arthurien de l'Alexandre de Cligès', Cahiers de recherches médiévales, 4 (1997) <http://crm.revues.org/index948.html> [accessed 10 July 2010] (para. 11 of 15). See also Donald Maddox and Sara Sturm-Maddox, 'Alexander the Great in the French Middle Ages’, in The Medieval French Alexander, ed. by D. Maddox and S. Sturm-Maddox (Albany: State University of New York Press, 2002), pp. 1-16.

${ }^{35}$ Here I profit from Guido Favati's discussion of this variant. He notes that 'à l'origine on n’y lisait pas estraiz, mais bien retraiz, et qu'ensuite seulement quelqu'un a exponctué $r$, et introduit un petit s à mi-hauteur entre $e$ et $t$ ' ('Le Cligès de Chrétien de Troyes’, p. 406). ${ }^{36}$ For the historical references to the 1180s fire at Saint-Pierre, the cathedral of Beauvais, see Pierre Louvet, Histoire et antiquités du diocèse de Beauvais, 2 vols (Beauvais: G. Valet, 1631-35), II, 308; Charles Delettre, Histoire du diocèse de Beauvais, 3 vols (Beauvais: Desjardins, 1842-43), I (1842), 61, II (1843), 174; and Victor Leblond, La Cathédrale de 
Beauvais (Paris: H. Laurens, 1926), p. 14. For the history of the church library see Henri A. Omont, Recherches sur la bibliothèque de l'église cathédrale de Beauvais (Paris: Imprimerie nationale, 1914).

${ }^{37}$ Kinoshita, 'Poetics of Translatio', p. 335.

${ }^{38}$ Favati, 'Le Cligès de Chrétien de Troyes’, p. 406.

${ }^{39}$ Levilson C. Reis, 'Odd Couple(t)s: (The) Guiot (Copy) and (the) Chrétien (Corpus)’, French Studies Bulletin, 30.112 (2009), 61-63.

${ }^{40}$ Érec et Énide, ed. by Jean-Marie Fritz, in Chrétien de Troyes, Romans, ed. by Zink, 1. 9.

${ }^{41}$ Douglas Kelly, 'Chrétien de Troyes', in Arthur of the French, ed. by Burgess and Pratt, pp. 135-85 (p. 135).

${ }^{42}$ Nixon, 'Catalogue of Manuscripts’, p. 7 n. 18.

${ }^{43}$ N. R. Ker, 'From “Above the Top Line” to "Below Top Line”: A Change in Scribal practice', Celtica, 5 (1960), 13-16 (p. 13).

${ }^{44}$ Nixon, 'Catalogue of Manuscripts', p. 7 n. 8. This new practice may explain the diverse later addition of titles in other manuscripts of Cligés, such as the addition of incipits to MS f. fr. 1450 in the thirteenth century and, again, modern titles in the fifteenth century; the inscription of post-medieval titles in the upper margins of MSS f. fr. 1374 and 1420, as discussed earlier; and the titling of works in the turn-of-the-century anthology MS f. fr. 375, contemporary with the manuscript (see ibid., pp. 31, 38, 42, 65).

${ }^{45}$ To account for the meaning of ll. 31-32 more precisely, I borrowed the wording 'belonged to’ from William W. Comfort's translation of Cligés in Chrétien de Troyes, Arthurian Romances (London: Dent, 1967). Comfort’s original passage reads: ‘Our books have 
informed us that the pre-eminence in chivalry and learning once belonged to Greece' (p. 91, my emphasis).

${ }^{46}$ For a complete discussion of the topoi of the translatio studii et imperii see Jacques Le Goff, Civilisation de l’Occident médiéval (Paris: Arthaud, 1964), pp. 218-20; A. G. Jongkees, 'Translatio studii: les avatars d'un thème médiéval', in Miscellanea mediaevalia in memoriam Jan Frederik Niermeyer (Groningen: Wolters, 1967), pp. 41-51; and Faith Lyons, 'Interprétations critiques au $\mathrm{XX}^{\mathrm{e}}$ siècle du prologue de Cligès: la translatio studii selon les historiens, les philosophes et les philologues', Euvres et critiques, 5.2 (1980-81), 39-44. On the valorization of the medieval concepts of chevalerie and clergie in the prologue to Cligés see Philippe Walter, ‘Transfert culturel et métissage de l'imaginaire: vers une théorie des mutations culturelles', Analele Universitaţii Bucureşti-Istorie, 46 (1997), 49-59; and Dominique Boutet, 'De la translatio imperii à la finis saeculi: progrès et décadence dans la pensée de l'histoire au Moyen Âge', in Progrès, réaction, décadence dans l'Occident médiéval, ed. by Emmanuèle Baumgartner and Laurence Harf-Lancner (Geneva: Droz, 2003), pp. 37-48.

${ }^{47}$ Chrétien de Troyes, Cligès, ed. by Rousse, pp. i-xxx (p. vii).

${ }^{48}$ Specifically, lines a31-32 in MS f. fr. 1420, fol. 30'; MS f. fr. 1374, fol. 21 ${ }^{\mathrm{v}}$; and MS f. fr. 375 , fol. $267^{\mathrm{v}}$.

${ }^{49}$ With slight dialectical differences, the line b28 of MS f. fr. 1450 , fol. $188^{\mathrm{v}}$, reads the same (as in line b29 of MS f. fr. 794, fol. 54): 'Qu'en Gresse ot de cevalerie.'

${ }^{50}$ Cligés, ed. by Gregory and Luttrell, p. 245 n. 36.

${ }^{51}$ Kelly, 'Chrétien de Troyes', in Arthur of the French, ed. by Burgess and Pratt, p. 171.

${ }^{52}$ Dictionnaire de l'ancienne langue française, ed. by Godefroy, v, 84. 
${ }^{53}$ For the various acceptations of maintenir see the Altfranzösisches Wörterbuch, ed. by Adolf Tobler and Erhard Lommatzsch, 11 vols (Berlin: Weidmann [vols 1-2]; Wiesbaden: Steiner [vols 3-11], 1925-), v (1963), 841-49, or the Dictionnaire de l'ancienne langue française, ed. by Godefroy, v, 84-85.

${ }^{54}$ On the conceptualization of a fictive Arthurian anterior order see Donald Maddox, The Arthurian Romances of Chrétien de Troyes: Once and Future Fictions (Cambridge: Cambridge University Press, 1991), p. 8.

${ }^{55}$ In all the other manuscripts (except MSS f. fr. 794 and 375), Cligés must measure up to the Britons and the French ('Et as Bretons et as François’, M-C, l. 2566).

${ }^{56}$ On the relationship between the topoi of the translatio as progress and the tempus senescit as decadence see Boutet, 'De la translatio imperii à la finis saeculi’, p. 38.

${ }^{57}$ According to Zumthor, the term mouvance designates “'le caractère de l’œuvre qui, comme telle, avant l'âge du livre, ressort d'une quasi-abstraction, les textes concrets qui la réalisent présentant, par le jeu de variantes et remaniements, comme une incessante vibration et une instabilité fondamentale’” (Essai, p. 507). 